\title{
Environmental factors influencing milk urea nitrogen in South African Holstein cattle
}

\author{
M.L. Kgole ${ }^{1,3 \#}$, C. Visser $^{1}$ \& C.B. Banga ${ }^{2}$ \\ ${ }^{1}$ Department of Animal and Wildlife Sciences, University of Pretoria, South Africa \\ ${ }^{2}$ ARC Animal Production Institute, Irene, South Africa \\ ${ }^{3}$ Livestock Research and Innovation Institute, Limpopo Department of Agriculture, South Africa
}

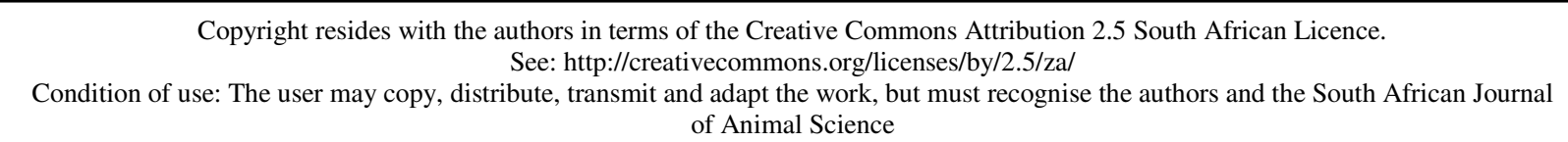

\begin{abstract}
By knowing the milk urea nitrogen (MUN) content of dairy cows, the efficiency of dietary nitrogen utilization can be improved. The main objectives of this study were to identify and quantify environmental factors affecting MUN in South African Holstein cows. This will enable better interpretation of MUN results by accounting for such factors. A total of 82900 test-day records of 9901 Holstein cows from 40 herds participating in the South African National Milk Recording and Improvement Scheme (NMRIS) during the period 2007 to 2010 were used. An analysis of variance was performed to determine environmental factors significantly affecting MUN. Significant factors were herd-test-day, year of calving, parity, number of times milked per day and lactation stage. Herd-test-day had the largest effect, accounting for $48.3 \%$ of the total variation. Trends in least squares (LS) means for MUN over lactation stages were similar for all parities; however, means were slightly lower in parity 3 than the first two parities. The LS mean for 2008 was the lowest $(13.9 \mathrm{mg} / \mathrm{dL})$ in comparison to other years. Cows milked twice daily had a higher MUN LS mean $(15.5 \mathrm{mg} / \mathrm{dL})$ in comparison to those milked three times per day $(13.4 \mathrm{mg} / \mathrm{dL})$. Results of this study provided the basis for proper use and better interpretation of MUN data.
\end{abstract}

Keywords: Milk urea nitrogen, environmental factors, dairy herd management

${ }^{\#}$ Corresponding author: kgoleml@agric.limpopo.gov.za

\section{Introduction}

The Holstein breed is one of four major South African dairy breeds that undergo routine genetic evaluation by the Agricultural Research Council's (ARC) Animal Production Institute (Mostert, 2007; SA Yearbook, 2009/10). In the 2010 test year, 29004 registered and 26571 commercial Holstein cows participated in performance testing in South Africa. This accounted for $41 \%$ and $48 \%$ of the registered and commercial cows in the national herd, respectively (NMRIS, 2010).

The concentration of urea in milk, commonly known as milk urea nitrogen (MUN), is an important tool in dairy herd management. It can be used to monitor the efficiency of utilization of dietary nitrogen (Jonker et al., 2002a; b), as well as to predict urinary nitrogen excretion (Burgos et al., 2007). Knowing the MUN levels in the herd assists dairy farmers in the nutritional management of their herds, as deviations from target MUN concentrations can be used to identify overfeeding or underfeeding of protein (Jonker et al., 1998; Kohn et al., 2002). The result would be a reduction of environmental nitrogen pollution through dietary manipulation and overall management adjustments (Schepers \& Meijer, 1998; Jonker et al., 2002a).

Although MUN has been routinely recorded for dairy cows in herds participating in the national milk recording scheme (NMRIS) since 1994, there has been limited research on the factors affecting MUN. The objective of this study was therefore to identify and quantify non-genetic factors affecting MUN levels in South African Holstein cattle. 


\section{Materials and Methods}

Test-day records and pedigree data of Holstein cows participating in the South African NMRIS during the period 2007 to 2010 were used. On test-days, each individual cow's milk was weighed and recorded at each milking. A milk sample was collected from each cow in milk at the evening milking. The MUN content, fat, protein and lactose percentage, and somatic cell count (SCC) were determined using a System 4000 Infrared Analyzer (Foss Electric, Hillerod, Denmark) at the Lacto Lab (Pty) Ltd at the ARC-Irene Institute. The data used in the current study were obtained from the Integrated Registration and Genetic Information System (Intergis). The original data set consisted of 1167293 test-day records of 10133 Holstein cows, with 909 herd-test-days. In Table 1 descriptive statistics for the original data set are presented.

Table 1 Descriptive statistics for test-day records for South African Holstein cows before editing

\begin{tabular}{lccccccccccccc}
\hline \multirow{2}{*}{ Trait } & \multicolumn{3}{c}{ Parity $1(\mathrm{n}=581$} & $150)$ & \multicolumn{4}{c}{ Parity $2(\mathrm{n}=425229)$} & \multicolumn{4}{c}{ Parity $3(\mathrm{n}=160914)$} \\
\cline { 2 - 13 } & Mean & SD & Min & Max & Mean & SD & Min & Max & Mean & SD & Min & Max \\
\hline MUN (mg/dL) & 15.3 & 3.7 & 4.0 & 28.0 & 15.5 & 3.7 & 6.0 & 30.0 & 15.5 & 3.7 & 5.0 & 27.0 \\
Milk yield (kg/d) & 24.7 & 8.5 & 1.0 & 98.0 & 27.8 & 10.2 & 3.0 & 95.0 & 28.8 & 10.5 & 1.0 & 97.0 \\
Fat yield (g/d) & 910 & 360 & 10 & 6210 & 1030 & 430 & 30 & 6050 & 1060 & 440 & 50 & 6050 \\
Protein yield (g/d) & 790 & 270 & 30 & 4010 & 890 & 310 & 20 & 3900 & 910 & 320 & 40 & 4030 \\
\hline
\end{tabular}

Age restrictions at calving, definition of seasons, yield limits and MUN concentration ranges were in accordance with data editing as performed in the South African Best Linear Unbiased Predictions (BLUP) analyses (Mostert et al., 2006). To ensure reasonable calving down ages in specific lactations, restrictions on age at calving were imposed, i.e. between 20 and 42, 30 and 54, and 40 and 66 months for the first, second, and third lactation, respectively (Mostert et al., 2006). Seasons of calving were defined as summer (October - March) and winter (April - September). Each lactation period was divided into 10 stages consisting of nine 30-day intervals each and one 35-day interval (Ojango \& Pollot, 2001). MUN records exceeding more than 3 standard deviations from the mean were removed from the data set, resulting in records ranging between 8 to $25 \mathrm{mg} / \mathrm{dL}$ range for individual cows. Milk yield, fat and protein percentage records exceeding $<2$ and $>90$ $\mathrm{kg},<2 \%$ and $>9 \%$, and $<2 \%$ and $>6 \%$, respectively, were regarded as outliers and were removed from the dataset. The final edited data set consisted of 82900 test-day records of 9901 cows from 40 herds and 927 herd-test-days. A summary of the number of animals and test-day records that were used for the subsequent data analysis is presented in Table 2. Observations from the three different parities were considered to be separate traits; hence, parities were analysed separately.

Table 2 The number of South African Holstein cows and test-day records per parity used in the analyses

\begin{tabular}{cccccc}
\hline & \multicolumn{5}{c}{ Number of records } \\
\cline { 2 - 6 } Parity & Records & HTD $^{1}$ & Cows & Sires & Dams \\
\hline 1 & 26391 & 703 & 4280 & 329 & 3778 \\
2 & 21313 & 727 & 3453 & 346 & 3120 \\
3 & 14889 & 697 & 2398 & 314 & 221 \\
\hline
\end{tabular}

${ }^{\mathrm{T}} \mathrm{HTD}=$ Number of herd-test-day records.

Descriptive statistics of all traits were computed using the Proc Means procedure of the Statistical Analysis System (SAS, 9.2). To determine non-genetic factors affecting MUN, an analysis of variance 
(ANOVA) was performed using the general linear model (GLM) procedure of SAS (SAS, 9.2). The following fixed effects model, in matrix notation, was used for the ANOVA:

$$
\mathbf{y}=\boldsymbol{\mu}+\mathbf{X b}+\mathbf{e}
$$

where $\mathbf{y}$ is a vector of observations for MUN; $\boldsymbol{\mu}$ is a vector of the mean for MUN observations; $\mathbf{b}$ is a vector of unknown fixed effects. $\mathbf{X}$ is an incidence matrix relating fixed effects to MUN observations. Fixed effects that were tested were herd-test-day (HTD), herd-year-season (HYS) of calving, year of calving, season of calving, season of test, age at calving, days in milk, number of times a cow was milked per day and two-way interactions among these factors. $\mathbf{e}$ is a vector of random residual errors.

\section{Results and Discussion}

The final data set had an overall mean of $14.2 \mathrm{mg} / \mathrm{dL}$ for MUN for cows in parity 1 . A similar mean of $14.4 \mathrm{mg} / \mathrm{dL}$ was obtained by Hojman et al. (2004) in Israeli dairy herds. Higher means of 17.9 and 30.4 $\mathrm{mg} / \mathrm{dL}$ were observed by Hossein-Zadeh \& Ardalan (2010) in Iranian Holstein cows and Abdouli et al. (2008) in Tunisian Holsteins. However, Wood et al. (2003) obtained a lower value $(12.6 \mathrm{mg} / \mathrm{dL})$ for Canadian Holsteins, in comparison to the current study. The overall mean for MUN in the current study was within the standard range $(8-25 \mathrm{mg} / \mathrm{dL})$ for cows participating in the South African National Dairy Animal Recording and Improvement Scheme. The means and standard deviations for MUN and the three production traits per parity are shown in Table 3 for all cows included in the study after editing.

Table 3 Means and standard deviations for milk urea nitrogen (MUN) and yield traits for South African Holstein cows in parities 1 to 3

\begin{tabular}{lcccccc}
\hline \multirow{2}{*}{ Trait } & \multicolumn{2}{c}{ Parity $1(\mathrm{n}=28844)$} & \multicolumn{2}{c}{ Parity $2(\mathrm{n}=23713)$} & \multicolumn{2}{c}{ Parity $3(\mathrm{n}=17$ 095) } \\
\cline { 2 - 7 } & Mean & SD & Mean & SD & Mean & SD \\
\hline MUN (mg/dL) & 14.2 & 3.3 & 14.4 & 3.3 & 14.3 & 3.2 \\
Milk yield (kg) & 26.0 & 8.3 & 29.6 & 10.0 & 30.5 & 10.2 \\
Fat yield (g) & 970 & 350 & 1120 & 470 & 1160 & 420 \\
Protein yield (g) & 830 & 250 & 950 & 300 & 970 & 300 \\
\hline
\end{tabular}

Mean MUN was lowest in the first parity, followed by an increase in the second parity and then a decrease in parity 3 . However, the differences between means of parities 1 to 3 were not significant $(P$ $<0.05)$. Although the means of the current study were generally higher, this trend was similar to those observed by Wood et al. (2003) and Mitchel et al. (2005).

Factors that had a significant effect $(P<0.01)$ on MUN variation, across parities, were herd-test-day (48.3\%), year of calving (1.2\%), stage of lactation (1.1\%), number of times milked per day $(0.04 \%)$ and milk $(0.02 \%)$, fat $(0.02 \%)$ and protein $(0.02 \%)$ yields. Stoop et al. (2007) found that herd-test-day (HTD) accounted for $58 \%$ of the total MUN variation. These results are supported by Wood et al. (2003) who reported effects of HTD to be highly significant $(P<0.00001)$.

Least square (LS) means by year of calving were similar for $2007(14.5 \mathrm{mg} / \mathrm{dL}), 2009(14.2 \mathrm{mg} / \mathrm{dL})$, and $2010(14.5 \mathrm{mg} / \mathrm{dL})$, but lower in $2008(13.9 \mathrm{mg} / \mathrm{dL})$. The differences in the means over the years could be due to different management practices or nutrition. As the data are limited to four years, it is difficult to tell if there is a trend over many years.

Trends in LS means for lactation stage over parity are shown in Figure 1. Trends in LS means for MUN over lactation stages were similar for all parities, which are in agreement with results of Jílek et al. (2006). The LS means for parity 3 were slightly lower compared to those of the first two parities. For all three parities, MUN was lowest in the first lactation stage and increased over the lactation period, reaching a peak in lactation stages 5 to 7 . These results concur with those observed in various other studies (Jílek et al., 2006; Abdouli et al., 2008; Cao et al., 2010). In contrast, other studies found no association between MUN and stage of lactation (Godden et al., 2001b; Hojman et al., 2004; Rajala-Schultz \& Saville, 2003). 


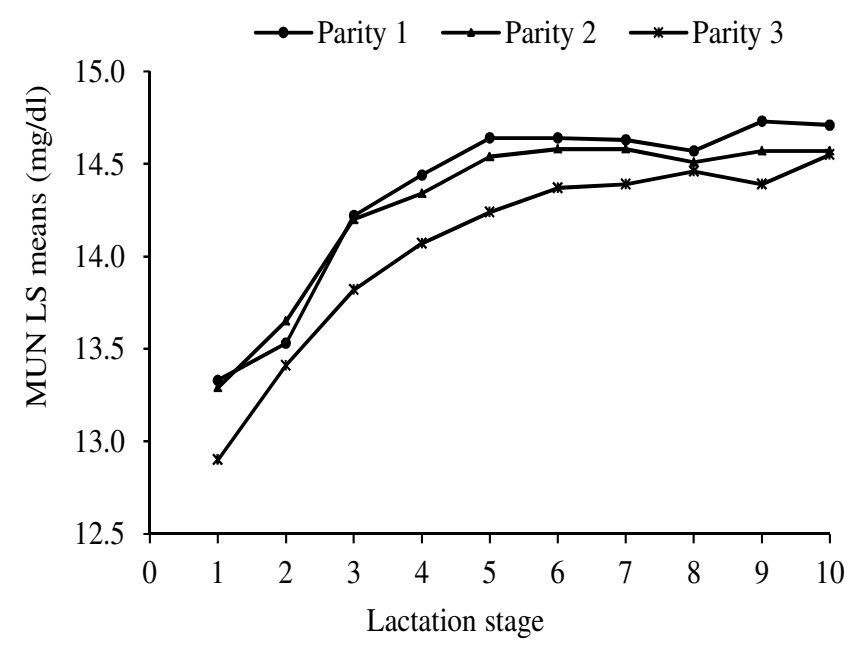

Figure 1 Trends in milk urea nitrogen (MUN) LS means for lactation stages of South African Holstein cows over parities 1 to 3 .

\section{Conclusion}

Environmental factors having a significant effect on MUN in South African Holstein cows include herd-test-day (HTD), year of calving, stage of lactation, number of times milked per day, and milk, fat and protein yields. The high contribution of HTD indicates that herd management and nutrition are important sources of variation in MUN. These factors should be taken into consideration when interpreting MUN results.

\section{References}

Abdouli, H., Rekik, B. \& Haddad-Boubaker, A., 2008. Non-nutritional factors associated with milk urea concentrations under Mediterranean conditions. Wrld J. Agric. Sci. 4, 183-188.

Burgos, S.A., Fadel, J.G. \& DePeters, E.J., 2007. Prediction of ammonia emission from dairy cattle manure based on milk urea nitrogen: Relation of milk urea nitrogen to urine urea nitrogen excretion. J. Dairy Sci. 90, 5499-5508.

Cao, Z., Huang, W., Wang, Y., Wen, W., Ma, M. \& Li, S., 2010. Effects of parity, days in milk, milk production and milk components on milk urea nitrogen in Chinese Holsteins. J. Anim. Vet. Adv. 9, 688-695.

Godden, S.M., Lissermere, K.D., Kelton, D.F., Leslie, K.E., Walton, J.S. \& Lumsden, J.H., $2001 b$. Relationships between milk urea concentrations and nutritional management, production, and economic variables in Ontario dairy herds. J. Dairy Sci. 84, 1128-1139.

Hojman, D., Kroli, O., Adin, G., Gips, M., Hanochi, B. \& Ezra, E., 2004. Relationships between milk urea and production, nutrition, and fertility traits in Israeli dairy herds. J. Dairy Sci. 87, 1001-1011.

Hossein-Zadeh, N.G. \& Ardalan, M., 2010. Estimation of genetic parameters for milk urea nitrogen and its relationship with milk constituents in Iranian Holsteins. Livest. Sci. doi: 10.1016/j.livsci.2010.07.020.

Jílek, F., Řehák, D., Volek, J., Štípkova, M., Němcová, E., Fiedlerová, M., Rajmon, R. \& Švestková, D., 2006. Effect of herd, parity, stage of lactation and milk yield on urea concentration in milk. Czech J. Anim. Sci. 51, 510-517.

Jonker, J.S., Kohn, R.A. \& Erdman, R.A., 1998. Using milk urea nitrogen to predict excretion and utilization efficiency in lactating dairy cows. J. Dairy Sci. 81, 2681-2692.

Jonker, J.S., Kohn, R.A. \& High, J., 2002a. Use of urea nitrogen to improve dairy cow diets. J. Dairy Sci. $85,939-946$. 
Jonker, J.S., Kohn, R.A. \& High, J., 2002b. Dairy herd management practices that impact nitrogen utilization efficiency. J. Dairy Sci. 85, 1218-1226.

Kohn, R.A., Kalscheur, K.F. \& Russek-Cohen, E., 2002. Evaluation of models to estimate urinary nitrogen and expected milk urea nitrogen. J. Dairy Sci. 85, 227-233.

Mitchel, R.G., Rogers, G.W., Vallimont, J.E., Cooper, J.B., Sander-Nielsen, U. \& Clay, J.S., 2005. Milk urea nitrogen concentration: Heritability and genetic correlations with reproductive performance and disease. J. Dairy Sci. 88, 4434-4440.

Mostert, B.E., 2007. The suitability of test-day models for genetic evaluation models for genetic evaluation of dairy cattle in South Africa. Ph.D. dissertation, Faculty of Natural and Agricultural Science, University of Pretoria.

Mostert, B.E., Theron, H.E., Kanfer, F.H.J. \& Van Marle-Köster, E., 2006. Test-day models for South African dairy cattle for participation in international evaluations. S. Afr. J. Anim. Sci. 36, 58-70.

National Milk Recording and Improvement Scheme, 2010. Annual report (statistics). Vol. 30. Agricultural Research Council, Animal Production Institute, Pretoria, South Africa.

Ojango, J.M. \& Pollot, G.E., 2001. Genetics of milk yield and fertility traits in Holstein-Friesian cattle on large-scale Kenyan farms. J. Anim. Sci. 79, 1742-1750.

Rajala-Schultz, P.J. \& Saville, W.J.A., 2003. Sources of variation in MUN in Ohio dairy herds. J. Dairy Sci. $86,1653-1661$.

SAS Institute Inc., Release 9.2, SAS Institute Inc., Cary, North Carolina, USA.

SA Yearbook 2009/10. Department of Agriculture, Forestry and Fisheries, South Africa.

Schepers, A.J. \& Meijer, R.G.M., 1998. Evaluation of the utilization of dietary nitrogen by dairy cows based on urea concentration in milk. J. Dairy Sci. 81, 579-584.

Stoop W.M., Bovenhuis, H. \& Van Arendonk, J.A.M., 2007. Genetic parameters for milk urea nitrogen in relation to milk reproduction traits. J. Dairy Sci. 90, 1981-1986.

Wood, G.M., Boettcher, P.J., Jamrozik, J., Jansen, G.B. \& Kelton, D.F., 2003. Estimation of genetic parameters for concentrations of milk urea nitrogen. J. Dairy Sci. 86, 2462-2469.

Yazgan, K., Makulska, J., Węglarz, A., Ptak, E. \& Gierdziewicz, M., 2010. Genetic relationship between milk dry matter and other milk traits in extended lactations of Polish Holstein cows. Czech J. Anim. Sci. 55, 91-104. 